\title{
Application of nitrogen fertilizer on plant density, growth, yield and fruit of bell peppers (Capsicum annuum L.)
}

\author{
G. Bhuvaneswari*, R. Sivaranjani, S. Reetha, K. Ramakrishan \\ Department of Botany, Annamalai University, Annamalai Nagar - 608 002, Tamil Nadu, India \\ *E-mail address: bhuvanalakshmi25@gamil.com
}

\begin{abstract}
The present research was carried out to evaluate response of Bell peppers (Capsicum annuum L.) to plant density and nitrogen fertilizer under field conditions. Plant density at four levels $(20 \times 50$ $\mathrm{cm}, 30 \times 50 \mathrm{~cm}, 20 \times 100 \mathrm{~cm}$ and $30 \times 100 \mathrm{~cm})$ and nitrogen treatments at four levels $(0,50,100$ and 150 $\mathrm{kg} \cdot \mathrm{N} \cdot \mathrm{ha}^{-1}$ ) were applied. Plant height, lateral stem number, leaf chlorophyll content, yield, and were assessed at immature and mature stages. The results showed that vegetative growth characteristics (plant height, lateral stem number and leaf dry matter) and reproductive factors (fruit volume and fruit weight) decreased with increasing plant density, but total yield $\left(\mathrm{kg} \cdot \mathrm{ha}^{-1}\right)$ increased with increasing plant density. The highest and lowest total yields were obtained by plant density $20 \times 50 \mathrm{~cm}$ and $30 \times 100 \mathrm{~cm}$ respectively. Nitrogen fertilizer was significantly affected on plant height, lateral stem number and leaf chlorophyll content. It was observed that fertilization with $150 \mathrm{~kg} \cdot \mathrm{N} \cdot \mathrm{ha}^{-1}$ resulted to the highest fruit volume and plant yield. There were significant differences between fruit volume and fruit weight by interaction between plant density and nitrogen treatments.
\end{abstract}

Keywords: Plant density; Nitrogen; Pepper; Yield; Fruit quality

\section{INTRODUCTION}

Vegetables are important sources of carbohydrates, proteins vitamins, and minerals. Bell peppers, the fruit of Capsicum annuum $\mathrm{L}$. is one of the most important commercial crops in India. With an annual production of 1.1 million tones, India is the largest producer of chilli in the world (Khan and Raj, 2006). Chilli (Capsicum annuum L.) which belongs to Solananceae, is known as a vegetable, and consumed both as fresh and dehydrated spices (Bosland and Vostava, 2000). Owing to its high cash value and consumption rate the annual trade of chilli is approximately $17 \%$ of total spice trade in the world (Ahmed et al., 2000) and is about $33 \%$ in India. However, the yield of chilli in India is substantially low when the large area (930,000 hectares) of production is considered (Bharathi et al., 2004). Capsicum is the most commonly cultivated species and all green chillies in the market and most of the dry chilies belong to this species. Chilli (Capsicum annuum L.) is an important tropical and subtropical crop on the basis of its high consumption, nutritional and cash value to farmers and consumers both in developed and developing countries, particularly in India. Sweet pepper is also known as bell pepper, green pepper or capsicum. It may be used as cooked or raw salad. 
The leaves as also consumed as salad, soups or eaten with rice. The yield depends upon several production factors. Among these proper, balanced nutrition plays a significant role.

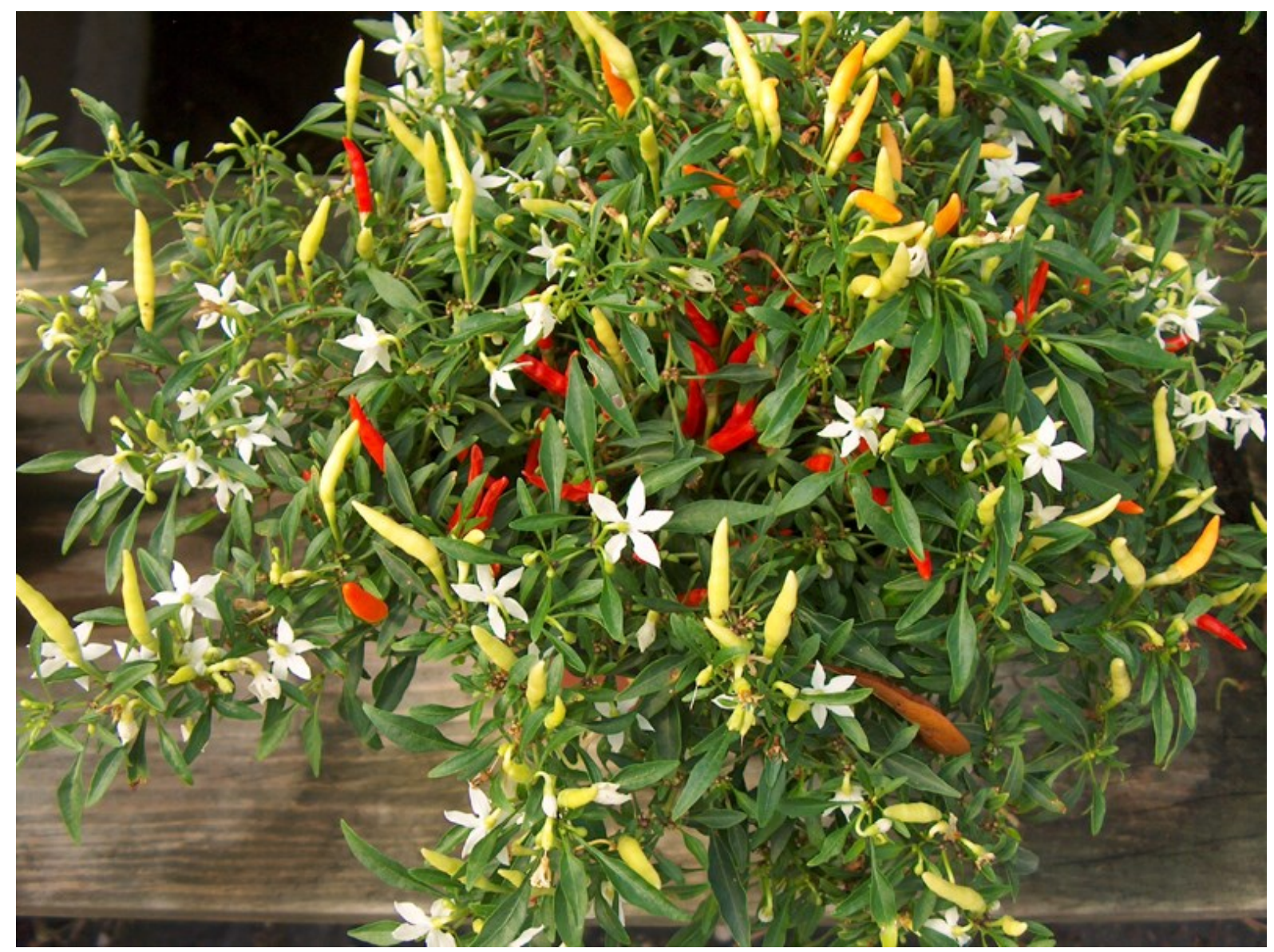

Photo 1. Chilli (Capsicum annuum L.).

Fertilizer is one of the major factors of crop production. Nitrogen is considered as one of the essential macronutrients required by the plants for their growth, development and yield. Moreover, nitrogen is the main constituent of all amino acids in proteins and lipids that acting as structural compounds of the chloroplast. Studies on plant density for plant development, growth and the marketable yield of pepper. Plant density is an important determinant of yield. Among the factors, nitrogen is very much essential for good plant establishment and expected growth (Uddin and Khalequzzaman, 2003). The largest natural source of nitrogen is the Earth's atmosphere, which is roughly $78 \%$ gaseous nitrogen, an inert and essentially biologically unavailable form of the element. These processes produce nitrogen in three main forms, each of which is available to plants: nitrate, nitrite, and ammonium (Wiedenhoeft, 2006).

Nasto et al. (2009) reported that increasing plant density resulted in greater yield $\left(\mathrm{kg} \cdot \mathrm{ha}^{-1}\right)$ of bell pepper. The increase in yield with higher plant density was as a result of increased numbers of fruit per ha in direct-seeded paprika pepper (Cavero et al., 2001). It had been observed that Nitrogen fertilizer is an essential component of any system in which the aim is to maintain good yield (Law and Egharevba, 2009). The productivity of pepper is 
highly responsive to $\mathrm{N}$ fertilizer. Tumbare et al. (2004) reported that nitrogen fertilizer increased fruit weight, yield and fruit number of chilli peppers.

Qawasmi et al. (1999) reported that increasing the rates of nitrogen applied in pepper plants increases the uptake of nitrogen by the plants and at the same time, stimulated the uptake of potassium and phosphorus through the synergistic effect of nitrogen on them. Therefore an experiment was conducted to identify a Bell pepper variety and to know its optimum spacing requirement for better growth and yield. Thus, the main aims of this experiment were to find the best plant density and nitrogen level for Bell pepper cultivation under field status.

\section{MATERIALS AND METHODS}

The investigation was conducted during the 2013 growing season at the experimental field condition of Botanical Garden, Department of Botany, Annamalai University. This site represents the range of dry conditions. The experimental field was cleared, ploughed, harrowed and divided into plots. Phosphorus $\left(\mathrm{P}_{2} \mathrm{O}_{5}\right)$ and potassium $\left(\mathrm{K}_{2} \mathrm{O}_{5}\right)$ were applied 50 and $100 \mathrm{~kg} / \mathrm{ha}$ each at the time of soil preparation. Sweet pepper seeds were established in a greenhouse in large trays with a 1:1 mixture of sand and peat $(1: 1 \mathrm{v} / \mathrm{v})$. Irrigation was done after sowing when necessary. Six-week-old pepper plants were hand-transplanted into wellprepared beds in the field. Other horticultural operations including mulching, weeding and harvest were done every week.

\section{1. Treatments}

Treatments consisted of four planting densities $(20 \times 50,30 \times 50,20 \times 100$ and $30 \times 100$ $\mathrm{cm})$ and four levels of nitrogen $\left(0,50,100\right.$, and $\left.150 \mathrm{~kg} \cdot \mathrm{ha}^{-1}\right)$ (Table 1). The source for nitrogenous fertilizer was urea $(46 \%)$ that was split into three equal parts and applied at ten days after transplanting (DAP) as basal and remaining portions were used as top dressing at 30 and 50 DAP.

Table 1. Treatments.

\begin{tabular}{|c|c|c|c|c|}
\hline \multirow{2}{*}{ Plant density $(\mathrm{cm})$} & \multicolumn{4}{|c|}{ Nitrogen fertilizer rate (kg/ha) } \\
\cline { 2 - 5 } & control & $\begin{array}{c}50 \mathrm{~kg} \\
(\mathrm{~N} / \mathrm{ha})\end{array}$ & $\begin{array}{c}100 \mathrm{~kg} \\
(\mathrm{~N} / \mathrm{ha})\end{array}$ & $\begin{array}{c}150 \mathrm{~kg} \\
(\mathrm{~N} / \mathrm{ha})\end{array}$ \\
\hline $20 \times 50$ & A1 & A2 & A3 & A4 \\
\hline $20 \times 100$ & B1 & B2 & B3 & B4 \\
\hline $30 \times 100$ & C1 & C2 & C3 & C4 \\
\hline $30 \times 100$ & D1 & D2 & D3 & D4 \\
\hline
\end{tabular}




\section{2. Measurements}

Ten plants in each replication were used to assess plant height, number of lateral stem at three growing stages including vegetative, flowering and reproductive. Leaf chlorophyll content was measured by a portable chlorophyll meter, SPAD-502 (Minolta Corporation, Ramsey, NJ). Leave samples were oven dried at $70{ }^{\circ} \mathrm{C}$ for 48 hours to the constant leaf dry weight for each plant, which was weighed using a digital balance (Basela and Mahadeen, 2008). Mature fruits were harvested at 10 to 14 days intervals to assess the volume of fruits $\left(\mathrm{cm}^{3}\right)$, average fruit weight $(\mathrm{g})$ and fruit yield per plant $(\mathrm{g} / \mathrm{plant})$. Fruit yield per hectare was obtained through conversion of the net plot yield.

\section{3. Experimental design and statistical analysis}

A $4 \times 4$ factorial experiment arranged in a completely randomized block design (RCBD) with three replications and each replication had 10 plants. Data were analyzed using MSTAT$\mathrm{C}$ and means were compared by Duncan's multiple range test (DMRT) at $5 \%$ level of confidence.

\section{RESULTS AND DISCUSSION}

Data (Tables 2 to 4) showed that plant density and nitrogen fertilization significantly affect pepper growth, yield and fruit quality.

\section{Vegetative growth}

\section{Plant height and lateral stem number}

\section{1. Effect of nitrogen}

Within the plant, nitrogen serves in the same ways as it does in other organisms as a component of amino acids and nucleic acids. Nitrogen also plays a critical role in the structure of chlorophyll, the primary light harvesting compound of photosynthesis. This, along with its structural role in amino acids, explains why plants require large amounts of nitrogen, and thus why it is often the limiting nutrient for plant growth. Nitrogen fertilizer application lead to increased plant height at vegetative and flowering stages (Table 2). The levels of 100 and $150 \mathrm{~kg} \cdot \mathrm{N} \cdot \mathrm{ha}^{-1}$ nitrogen fertilizer produced the tallest plants and the shortest plants were formed in the control; however, no significant difference was found between three treatments: 50,100 and $150 \mathrm{~kg} \cdot \mathrm{N} \cdot \mathrm{ha}^{-1}$.

The obtained results were in agreement with others (Bar et al., 2001; Bowen and Frey, 2002). Height of plant can be considered as one of the indices of plant vigor ordinarily and it depends upon vigor and growth habit of the plant. Soil nutrients are also very important for the height of plants. Nitrogen gives dark-green colour to plants and increases the vegetative growth of crop-plants. It plays a key role in the preparation of starch in leaves and production of amino acids. It improves the quality of leafy vegetables and fodders and protein content of food-grains. Plants contain 1-5\% nitrogen by weight. Excess of $\mathrm{N}$ leads to excessive succulent growth and susceptibility to pests and diseases. Therefore, a higher dose of nitrogen increased plant height (Pervez et al., 2004). 
Table 2. Effect of plant density and Nitrogen fertilizer application on vegetative characteristics of pepper (plant height $\mathrm{cm}$ ).

\begin{tabular}{|c|c|c|c|}
\hline \multirow{2}{*}{ Treatments } & \multicolumn{2}{|c|}{ Plant height (cm) } & Lateral stem number \\
\hline & Veg. & flower & Veg. \\
\hline $20 \times 50 \mathrm{~cm}$ with $\mathrm{N}(0)$ & $7.10 \pm 0.00$ & $14.13 \pm 0.01$ & $5.10 \pm 0.05$ \\
\hline $20 \times 50 \mathrm{~cm}$ with $\mathrm{N}(50)$ & $7.29 \pm 0.01$ & $14.26 \pm 0.17$ & $6.01 \pm 0.15$ \\
\hline $20 \times 50 \mathrm{~cm}$ with $\mathrm{N}(100)$ & $7.29 \pm 0.01$ & $14.25 \pm 0.05$ & $6.14 \pm 0.04$ \\
\hline $20 \times 50 \mathrm{~cm}$ with $\mathrm{N}(150)$ & $7.58 \pm 0.04$ & $15.04 \pm 0.05$ & $6.09 \pm 0.05$ \\
\hline $20 \times 100 \mathrm{~cm}$ with $\mathrm{N}(0)$ & $7.28 \pm 0.05$ & $14.17 \pm 0.23$ & $5.19 \pm 0.15$ \\
\hline $20 \times 100$ cm with $\mathrm{N}(50)$ & $7.37 \pm 0.25$ & $14.31 \pm 0.01$ & $6.10 \pm 0.15$ \\
\hline $20 \times 100 \mathrm{~cm}$ with $\mathrm{N}(100)$ & $7.29 \pm 0.26$ & $14.33 \pm 0.01$ & $6.15 \pm 0.03$ \\
\hline $20 \times 100 \mathrm{~cm}$ with $\mathrm{N}(150)$ & $7.30 \pm 0.02$ & $14.17 \pm 0.01$ & $5.19 \pm 0.01$ \\
\hline $30 \times 50 \mathrm{~cm}$ with $\mathrm{N}(0)$ & $7.28 \pm 0.05$ & $14.16 \pm 0.01$ & $5.17 \pm 0,02$ \\
\hline $30 \times 50 \mathrm{~cm}$ with $\mathrm{N}(50)$ & $7.32 \pm 0.02$ & $14.30 \pm 0.02$ & $6.12 \pm 0.03$ \\
\hline $30 \times 50 \mathrm{~cm}$ with $\mathrm{N}(100)$ & $7.26 \pm 0.02$ & $14.28 \pm 0.01$ & $6.09 \pm 0.03$ \\
\hline $30 \times 50$ cm with $\mathrm{N}(150)$ & $7.26 \pm 0.02$ & $14.31 \pm 0.28$ & $6.13 \pm 0.25$ \\
\hline $30 \times 100 \mathrm{~cm}$ with $\mathrm{N}(0)$ & $7.40 \pm 0.02$ & $14.34 \pm 0.01$ & $6.11 \pm 0.15$ \\
\hline $30 \times 100 \mathrm{~cm}$ with $\mathrm{N}(50)$ & $7.31 \pm 0.03$ & $14.35 \pm 0.01$ & $6.16 \pm 0.26$ \\
\hline $30 \times 100 \mathrm{~cm}$ with $\mathrm{N}(100)$ & $7.34 \pm 0.01$ & $14.17 \pm 0.05$ & $5.20 \pm 0.05$ \\
\hline $30 \times 100 \mathrm{~cm}$ with $\mathrm{N}(150)$ & $7.34 \pm 0.1$ & $14.18 \pm 0.01$ & $5.20 \pm 0.01$ \\
\hline
\end{tabular}

Vegetative stage (veg.), flowering stage (flower)

The values are mean \pm SD for samples in each group

The effect of nitrogen fertilizer on the lateral stems number of pepper was significant (Table 3). The highest number of lateral stems $(6.15 \pm 0.03)$ was obtained at $100 \mathrm{~kg} \cdot \mathrm{N} \cdot \mathrm{ha}^{-1}$ (at vegetative stage); nitrogen promotes growth and increased biomass production and Nitrogen fertilization has been used to increase grown and yield of capsicum plant.

\section{2. Effect of plant density}

Results obtained indicated significant differences for plant height (Table 3). The highest plant heights (at vegetative and flowering stages) were observed in density $30 \times 100$ $\mathrm{cm}$ with $(7.34 \pm 0.01)$ and $(14.18 \pm 0.01 \mathrm{~cm})$ respectively and these variables decreased as 
plant density increased. Similar results were also reported by others (Elattir, 2002; Viloria et al., 2002; Ara et al., 2007). The effect of plant density on the lateral stems number of pepper was significant. The plant density also had significant effect on lateral stems number (Table $3)$. The highest lateral stems number $(6.20 \pm 0.02 \mathrm{~cm})$ was obtained at $30 \times 100 \mathrm{~cm}$; however, no significant difference was found between treatments at flowering stage. This result is the same trend with the findings of Jovicich and Cantliffe (2002) and Majnoun et al. (2006). Forbes and Watson (1994) explained that as plant population density increases, competition for available water, mineral nutrients and light increases (Samih, 2008). The productivity of the plant at high plant density can vary depending on the number of shoots per plant. Plant density and number of shoot do not affect the fruit characteristics when the fruit is harvested at the same stage of development.

Table 3. Effect of plant density and nitrogen fertilizer application on vegetative characteristics of pepper (leaf chlorophyll, leaf dry matter).

\begin{tabular}{|c|c|c|c|c|}
\hline \multirow{2}{*}{ Treatments } & \multicolumn{2}{|c|}{ Leaf chlorophyll } & \multicolumn{2}{c|}{ Leaf dry matter } \\
\cline { 2 - 5 } & Veg. & Flower & Veg. & Flower \\
\hline $20 \times 50 \mathrm{~cm}$ with N(0) & $48.43 \pm 0.05$ & $46.75 \pm 0.05$ & $12.02 \pm 0.17$ & $18.12 \pm 0.05$ \\
\hline $20 \times 50 \mathrm{~cm}$ with $\mathrm{N}(50)$ & $50.12 \pm 0.01$ & $51.23 \pm 0.01$ & $12.19 \pm 0.15$ & $18.27 \pm 0.10$ \\
\hline $20 \times 50 \mathrm{~cm}$ with $\mathrm{N}(100)$ & $50.12 \pm 0.11$ & $51.20 \pm 0.08$ & $12.25 \pm 0.01$ & $18.27 \pm 0.10$ \\
\hline $20 \times 50 \mathrm{~cm}$ with $\mathrm{N}(150)$ & $50.06 \pm 0.55$ & $51.26 \pm 0.02$ & $12.17 \pm 0.01$ & $18.27 \pm 0.01$ \\
\hline $20 \times 100 \mathrm{~cm}$ with $\mathrm{N}(0)$ & $48.53 \pm 0.40$ & $47.18 \pm 0.03$ & $12.14 \pm 0.04$ & $18.17 \pm 0.03$ \\
\hline $20 \times 100 \mathrm{~cm}$ with $\mathrm{N}(50)$ & $50.24 \pm 0.10$ & $51.28 \pm 0.02$ & $12.28 \pm 0.03$ & $18.31 \pm 0.01$ \\
\hline $20 \times 100 \mathrm{~cm}$ with $\mathrm{N}(100)$ & $50.31 \pm 0.03$ & $51.31 \pm 0.01$ & $12.34 \pm 0.01$ & $18.32 \pm 0.05$ \\
\hline $20 \times 100 \mathrm{~cm}$ with $\mathrm{N}(150)$ & $50.30 \pm 0.03$ & $51.28 \pm 0.03$ & $12.33 \pm 0.05$ & $18.29 \pm 0.05$ \\
\hline $30 \times 100 \mathrm{~cm}$ with $\mathrm{N}(0)$ & $48.26 \pm 26$ & $47.10 \pm 0.05$ & $12.08 \pm 0.20$ & $18.20 \pm 0.01$ \\
\hline $30 \times 50 \mathrm{~cm}$ with $\mathrm{N}(50)$ & $50.27 \pm 0.02$ & $51.23 \pm 0.15$ & $12.26 \pm 0.20$ & $18.31 \pm 0.02$ \\
\hline $30 \times 50 \mathrm{~cm}$ with $\mathrm{N}(100)$ & $50.25 \pm 0.05$ & $51.28 \pm 0.11$ & $12.33 \pm 0.05$ & $18.31 \pm 0.01$ \\
\hline $30 \times 50 \mathrm{~cm}$ with $\mathrm{N}(150)$ & $50.25 \pm 0.05$ & $51.26 \pm 0.11$ & $12.30 \pm 0.01$ & $18.31 \pm 0.01$ \\
\hline
\end{tabular}

Vegetative stage (veg.), flowering stage (flower)

The values are mean \pm SD for samples in each group 


\section{3. Leaf chlorophyll content}

The effect of nitrogen fertilizer level on leaf chlorophyll content was significant (Table 3 ). Results indicated the highest and lowest leaf chlorophyll content were observed at 50 $\mathrm{kg} \cdot \mathrm{N} \cdot \mathrm{ha}^{-1}$ and control plants (at vegetative and flowering stages) but there was no significance between nitrogen levels at the reproductive stage. Similar results have been reported in investigations conducted by Bowen and Frey (2002), Aroiee and Omidbaigi (2004) and Basela et al. (2008). A promotion effect of inorganic fertilizers on chlorophyll contents might be attributed to the fact that nitrogen is a constituent of chlorophyll molecule. Moreover, nitrogen is the main constituent of all amino acids in proteins and lipids that act as structural compounds of the chloroplast (Basela and Mahadeen, 2008). Nitrogen is the most important nutrient and required by the plant in largest proportion. It is the important constituent of chlorophyll, protoplasm, protein and nucleic acids. It is most important for preparation of starch in leaves and production of amino acids.

\section{4. Effect of plant density}

Plant density significantly did not effect on leaf chlorophyll contents.

\section{5. Leaf dry matter content}

The application of nitrogen fertilizer level on leaf chlorophyll content was significant (Table 3 ) but the difference between 50,100 , and $150 \mathrm{~kg} \cdot \mathrm{ha}^{-1}$. The highest leaf dry matter content was obtained at 50 and $100 \mathrm{~kg} \cdot \mathrm{N} \cdot \mathrm{ha}^{-1}$ application (at vegetative and flowering stages respectively) while the least leaf dry matter content was obtained in the control. Similarly, Balliuet, et al. (2008) Magdatena (2003) reported that leaf dry matter content increased as nitrogen rate increased.

Takebe et al. (1995) reported that increments in leaf dry weight may be due to a combination of nitrogen with plant matter produced during photosynthesis such as glucose, ascorbic acid, amino acids and protein. It was found that the increase of the $\mathrm{N}$ concentration in the nutrient solution stimulated dry mass accumulation, stem elongation and leaf expansion rate, but decreased the root.

\section{6. Reproductive growth}

\section{Fruit weight $(\mathrm{g})$ and length $\left(\mathrm{cm}^{3}\right)$}

Nitrogen fertilizer significantly affected the average fruit weight and fruit volume (4) Data showed that the highest fruit weight and volume fruit were observed from 50 and 100 $\mathrm{kg} \cdot \mathrm{N} \cdot \mathrm{ha}^{-1}$ treatments $\left(50.55 \pm 0.05 \mathrm{~g}, 64.71 \pm 0.07 \mathrm{~cm}^{3}\right)$, while the lowest belonged to the control $\left(49.44 \mathrm{~g}, 51.00 \pm 0.03 \mathrm{~cm}^{3}\right)$. These results are consistent with those reported by Bar et al. (2001), Magdatena (2003), Akanbi et al. (2007) and Aujla et al. (2007) who also reported that increasing the rate of nitrogen fertilizers increases the average fruit weight and volume of pepper. Plant density $20 \times 100 \mathrm{~cm}$ with $100 \mathrm{~kg} \mathrm{~N} \cdot \mathrm{ha}^{-1}$, while the lowest fruit weight $(2.85$ $\pm 0.01 \mathrm{~g})$ and fruit length $\left(115.0 \mathrm{~cm}^{3}\right)$ was related to plant density $20 \times 50$ and $30 \times 50 \mathrm{~cm}$ respectively.

Gene (2002) and Jovicich and Cantliffe (2003) reported similar findings with increasing average fruit weight with wider spacing. Changes in growth differences could be attributed to reduced competition for available nutrients in the soil and light energy. While higher planting 
densities adversely affect growth and yield of individual plants, total biomass produced per unit area increase with density. Thus within limits, high density planting compensate for the decreased weight of the individual plants. Thus, our study shows that application of nitrogen fertilizer is recommended for Bell pepper plant production and could be a concern for growers (Table 4).

Table 4. Effect of plant density and nitrogen fertilizer application on fruit fresh weight and fruit length of pepper.

\begin{tabular}{|c|c|c|}
\hline Treatments & Fruit F. W (g) & Fruit length $\left(\mathrm{cm}^{3}\right)$ \\
\hline $20 \times 50 \mathrm{~cm}$ with $\mathrm{N}(0)$ & $49.44 \pm 0.01$ & $53.04 \pm 0.53$ \\
\hline $20 \times 50 \mathrm{~cm}$ with $\mathrm{N}(50)$ & $50.00 \pm 0.05$ & $56.03 \pm 0.58$ \\
\hline $20 \times 50 \mathrm{~cm}$ with $\mathrm{N}(100)$ & $52.26 \pm 0.36$ & $60.04 \pm 0.05$ \\
\hline $20 \times 50$ cm with $\mathrm{N}(150)$ & $50.16 \pm 0.13$ & $55.08 \pm 0.07$ \\
\hline $20 \times 100 \mathrm{~cm}$ with $\mathrm{N}(0)$ & $48.89 \pm 1.01$ & $54.01 \pm 0.23$ \\
\hline $20 \times 100 \mathrm{~cm}$ with $\mathrm{N}(50)$ & $50.48 \pm 0.03$ & $63.06 \pm 0.60$ \\
\hline $20 \times 100 \mathrm{~cm}$ with $\mathrm{N}(100)$ & $50.55 \pm 0.05$ & $67.65 \pm 0.75$ \\
\hline $20 \times 100 \mathrm{~cm}$ with $\mathrm{N}(150)$ & $50.48 \pm 0.01$ & $67.64 \pm 0.09$ \\
\hline $30 \times 50 \mathrm{~cm}$ with $\mathrm{N}(0)$ & $49.49 \pm 0.01$ & $51.00 \pm 0.03$ \\
\hline $30 \times 50 \mathrm{~cm}$ with $\mathrm{N}(50)$ & $50.01 \pm 0.01$ & $61.34 \pm 1.05$ \\
\hline $30 \times 50 \mathrm{~cm}$ with $\mathrm{N}(100)$ & $49.90 \pm 0.77$ & $64.71 \pm 0.07$ \\
\hline $30 \times 50 \mathrm{~cm}$ with $\mathrm{N}(150)$ & $49.85 \pm 0.01$ & $63.17 \pm 0.57$ \\
\hline $30 \times 100 \mathrm{~cm}$ with $\mathrm{N}(0)$ & $49.06 \pm 1.10$ & $51.54 \pm 0.18$ \\
\hline $30 \times 100 \mathrm{~cm}$ with $\mathrm{N}(50)$ & $53.51 \pm 5.17$ & $65.58 \pm 0.71$ \\
\hline $30 \times 100 \mathrm{~cm}$ with $\mathrm{N}(100)$ & $50.59 \pm 0.04$ & $67.01 \pm 0.03$ \\
\hline $30 \times 100 \mathrm{~cm}$ with $\mathrm{N}(150)$ & $50.54 \pm 0.05$ & $63.55 \pm 1.09$ \\
\hline
\end{tabular}

Fresh weight (F.W)

The values are mean \pm SD for samples in each group

\section{CONCLUSIONS}

In conclusion, within-row spacing and the number of shoots affect the productivity of pepper plants. The productivity of the plant at high plant density can vary depending on the number of shoots per plant. In order to obtain a high yield from the unit area in the field condition. Plant density and number of shoots do not affect the fruit characteristics when the 
fruit is harvested at the same stage of development. The improvement occurred in the plant growth and development could be attributed to effects of nutrients plant growth regulators synthesis in growing plant. Although higher nitrogen level increased vegetative growth of Chilli plant, however, reproductive growth was enhanced with the lowest level of Nitrogen. On the other hand, there were no significant differences between $\mathrm{N}$ levels on almost all cases of variables; however, they were improved with lower nitrogen levels. Under our experiment conditions, this plant showed a good response to the lowest $\mathrm{N}$ level, but we cannot recommend this level to all soils or climatic conditions, which justify site specific and need, based nutrient management. Nitrogen promotes growth and increases biomass production, and nitrogen fertilization has been used to increase growth and yield of Chilli plant.

\section{References}

[1] Aujla M. S., Thind H. S., Buttar G. S., J. Sci. Hortic. 112 (2007) 142-148.

[2] Ahmed J., Shivhare U. S., Raghavan G. S. V., J. Food Eng. 44 (2000) 239-244.

[3] Bar-Tal A., Aloni B., Karin L., Rosenberg R., J. Hort. Sci. 36 (2001) 1525-1529.

[4] Bharathi R., Vivekananthan R., Harish S., Ramanathan A., Samiyappan R., Crop Prot. 23 (2004) 835-843.

[5] Bosland P. W., Vostava E. J. (2000). Peppers: vegetable and spice capsicum. CABI publishing, New York, USA.

[6] Cavero J., Ortega Gill R., Gutierrez M., Hort. Sci. 361(1) (2001) 76-79.

[7] Elattir H., Acta Hort. 613 (2002) 197-200.

[8] Gene M., Acta Hort. 613 (2002) 107-109.

[9] Khan M. S., Raj S. K., Plant Pathol. 55 (2006) 822.

[10] Law-Ogbomo K., Egharevba E., World J. Agric. Sci. 5(2) (2009) 152-158.

[11] Nasto T. H., Balliu A., Zeka N., Acta Hort. 830 (2009) 906-912.

[12] Magdatena V. C., J. Soil Sci. 67 (2003) 1781-1789.

[13] Pervez M. A., Ayub C. M., Bashart A., Nave A. V., Nasir M., Int. J. Agric. Biol. 6(3) (2004) 504-506.

[14] Qawasmi W., Munir J. M., Najim H., Remon Q., J. Commun. Soil Sci. Plant Anal. 30(17) (1999) 2499-2509.

[15] Singh D. K., Jain S. K., Scientific Horticulture 9 (2004) 97-100.

[16] Takebe M., Ishihara T., Matsuna K., Fojimoto J., Yoneyama T., Jpn. J. Soil Sci. Plant Nutr. 66 (1995) 238-246.

[17] Tumbare A. D., Niikam D. R., Indian J. Agric. Sci. 74 (2004) 242-245.

[18] Uddin M. K., Khalequzzaman K. M., Pakistan J. Bio. Sci. 6(6) (2003) 605-609.

[19] Wiedenhoeft A. C. (2006). Plant nutrition. Hopkins WG (Eds) the green world, Chelsea House publisher, New York NY. Pp. 16-43. 
[20] E. Sanjai Gandhi, A. Sri Devi, L. Mullainathan, International Letters of Natural Sciences 5 (2014) 18-23.

[21] L. Mullainathan, A. Sridevi, S. Umavathi, E. Sanjai Gandhi, International Letters of Natural Sciences 6 (2014) 1-8.

( Received 01 April 2014; accepted 08 April 2014 ) 